\title{
Pengaruh Pemberian Vitamin B6 dan Vitamin B12 Terhadap Konsentrasi Homosistein Serum pada Pasien Leukemia Limfoblastik Akut
}

Julispen S. Muhi, Fadil Oenzil, ${ }^{*}$ Amirah Zatil Izzah

Bagian Ilmu Kesehatan Anak Fakultas Kedokteran /RS Dr. M. Djamil Padang, "Bagian Ilmu Biokimia Fakultas Kedokteran Universitas Andalas

Latar belakang. Leukemia merupakan 35\% keganasan pada anak. Persentase terbanyak adalah Leukemia limfoblastik akut (LLA) yang mencapai 80\%. Pedoman kemoterapi LLA berdasarkan Indonesian Childhood ALL-Protocol 2013 menggunakan metotreksat (MTX) intratekal dan intravena, bekerja menghambat enzim dihidrofolat reduktase (DHFR) menyebabkan peningkatan konsentrasi homosistein yang mempunyai efek neurotoksisitas. Vitamin B6 dan B12 adalah kofaktor enzim yang berperan pada remethylation dan transsulferation yang dapat menurunkan konsentrasi homosistein.

Tujuan. Mengetahui pengaruh vitamin B6 dan B12 terhadap konsentrasi homosistein pada pasien LLA yang mendapat MTX intratekal (MTX IT) dan MTX intravena dosis tinggi (high dose/MTX HD).

Metode. Penelitian case control study pre dan post control group design pada pasien LLA yang dirawat di bagian Anak RS Dr. M.Djamil Padang dari Januari-Juni 2017. Jumlah sampel kelompok kontrol dan perlakuan 10 orang. Kelompok perlakuan mendapat vitamin B6 $20 \mathrm{mg} /$ hari dan B12 0,5 mg/hari selama 6 minggu.

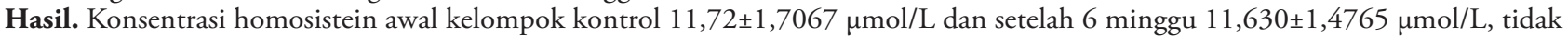
berbeda bermakna secara statistik ( $>>0,05)$. Kelompok perlakuan, konsentrasi awal 12,05 $\pm 2,0919 \mu$ mol/L dan setelah 6 minggu $10,07 \pm 1,6526 \mu \mathrm{mol} / \mathrm{L}$, berbeda bermakna secara statistik ( $\mathrm{p}<0,05)$. Pemberian vitamin B6 $20 \mathrm{mg} / \mathrm{hari}$ dan B12 0,5 mg/hari menurunkan rerata konsentrasi homosistein $1,98 \pm 0,8108 \mu \mathrm{mol} / \mathrm{L}$, bermakna secara statistik $(\mathrm{p}<0,05)$.

Kesimpulan. Pemberian vitamin B6 dan B12 pada pasien LLA yang mendapatkan MTX IT dan MTX HD dapat menurunkan rerata konsentrasi homosistein. Sari Pediatri 2018;20(3):158-64

Kata kunci: LLA, metotreksat, homosistein, neurotoksisitas, vitamin B6, B12

\section{The Influence of Vitamin B6 and B12 on The Homocysteine Serum Concentration on The Patients of Acute Limphoblastic Leukemia}

Julispen S. Muhi, Fadil Oenzil, ${ }^{*}$ Amirah Zatil Izzah

Background. Leukemia is $35 \%$ of malignancy in children, most of them Acute Lymphoblastic Leukemia (ALL) are $80 \%$. The ALL
chemotherapy guidelines currently used The Indonesian Childhood ALL Protocol 2013, intravenous and intrathecal methotrexate
(MTX). The mechanism of MTX inhibits the enzyme dihydrofolate reductase (DHFR) thereby increasing of serum homocysteine,
it has the effect of neurotoxicity. Vitamin B6 and B12, enzyme cofactors a role in remethylation and transsulferation can decrease
of homocysteine concentrations.
Objective. The purpose of this study was to determine the effect of vitamin B6, B12 on homocysteine concentrations in ALL patients
receiving intrathecal MTX (IT MTX) and high dose MTX (HD MTX).
Methods. The study a case-control study with pre and post control group design, it was ALL patients treated in the RS Dr. M.Djamil
Padang January-June 2017 . The number of control and treatment group samples was 10 people, respectively. The treatment group
received vitamin B6 $20 \mathrm{mg} /$ day and B12 $0.5 \mathrm{mg} /$ day for 6 weeks.
Results. Homocysteine concentration of initial control group was $11.72 \pm 1.7067 \mu$ mol/L and after 6 weeks $11.630 \pm 1.4765 \mu$ mol/L,
no statistically significant difference (p> 0.05 ). On the treatment group, the initial concentration was $12.05 \pm 2.0919 \mu$ mol/L and
after 6 weeks $10.07 \pm 1.6526 \mu$ mol/L, differed statistically significant (p<0.05). Giving of vitamin B6 20 mg/day and B12 0.5 mg/day
decreased homocysteine concentration as much as $1,98 \pm 0.8108 \mu$ mol/L, statistically significant $(\mathrm{p}<0.05$ ).
Conclusions. Provision of vitamin B6 and B12 in ALL patients receiving IT MTX and HD MTX may decrease average homocysteine
concentrations. Sari Pediatri $2018 ; 20(3): 158-64$

Keywords: $A L L$, metotrexate, homocysteine, neurotoxicity, vitamin B6, B12

Alamat korespondensi: Julispen S. Muhi. Bagian Ilmu Kesehatan Anak Fakultas Kedokteran Universitas Andalas/RS Dr. M. Djamil Padang. Email: julispens.muhi@yahoo.com 
Julispen S. Muhi dkk: Pengaruh pemberian vitamin B6 dan vitamin B12 terhadap konsentrasi homosistein serum pada LLA

$\mathrm{L}$ eukemia merupakan keganasan hematologik akibat proses neoplastik yang disertai gangguan diferensiasi pada berbagai tingkatan stem sel. ${ }^{1}$ Leukemia merupakan $35 \%$ dari keganasan pada anak, terbanyak (80\%) adalah leukemia limfoblastik akut (LLA)., ${ }^{2,3}$ Di Indonesia, diperkirakan sekitar 3000 kasus LLA baru pada anak setiap tahunnya. ${ }^{4}$ Pedoman kemoterapi yang digunakan berdasarkan Indonesian Childhood ALL-Protocol 2013) dengan penggunaan obat, antara lain, steroid, vincristine, L-asparginase, cytarabine, daunorubicin, siklofosfamid, mercaptopurine, leukoverin dan metotreksat, baik oral, intravena maupun intratekal., Metotreksat (MTX) merupakan komponen integral dari pengobatan leukemia. MTX intratekal (MTX IT) dan MTX high dose (MTX HD) dapat menyebabkan efek samping neurotoksisitas subakut, akut dan kronis, mulai dari tanpa gejala sampai perubahan demielinasi substansia alba cerebri..$^{7-9}$ Neurotoksisitas disebabkan oleh berbagai faktor, antara lain, faktor jumlah paparan kumulatif pemberian MTX, rute pemberian MTX (IT dan IV), dengan insiden 5\%-18\%. . $^{5-9}$

Neurotoksisitas yang disebabkan oleh MTX mengakibatkan kerusakan substansia alba berupa leukoencephalopathy (LEP) sebesar 9\%-53\%, dengan gambaran pencitraan MRI (Magnetic Resonance Imaging) berupa hiperintensitas, dengan angka kejadian 67\% setelah pemberian MTX IT dan 75\% setelah pemberian MTX HD. ${ }^{5,7,9}$ Efek tersebut timbul karena mekanisme kerja MTX menghambat enzim dihidrofolat reduktase (DHFR), yaitu enzim yang berfungsi mengubah dihidrofolat menjadi tetrahidrofolat sehingga meningkatkan adenosine dan homosistein. Peningkatan konsentrasi homosistein memengaruhi sintesis katekolamin, penurunan neurotransmitter aminobiogenik, gangguan $N$-methyl-D-aspartate (NMDA) reseptor dan perubahan metabolisme biopterin sehingga menyebabkan gangguan demielinisasi, gangguan kognitif dan demensia, kerusakan oksidatif, kerusakan proliferasi selular otot polos vaskuler, gangguan neurotransmitter glutamat, kerusakan mitokondria dan kerusakan DNA neuron yang menimbulkan kerusakan sel neuron. ${ }^{5,6,9}$

Metabolisme homosistein dikendalikan oleh dua jalur, yaitu katabolisme dan remetilasi. Metabolisme ini sangat tergantung pada vitamin B6 dan B12. ${ }^{10}$ Penelitian Strain $\mathrm{dkk}^{11}$ mendapatkan pemberian vitamin B12 dengan dosis $0,5 \mathrm{mg} /$ hari dan vitamin B6 dosis $16,5 \mathrm{mg} /$ hari akan mengurangi $7 \%$ konsentrasi homosistein, dan bila ditambah dengan pemberian asam folat akan menurunkan konsentrasi homosistein $25 \%$, karena peningkatan konsentrasi homosistein $>12,0 \mu \mathrm{mol} / \mathrm{L}$ sebagai penanda metabolik fungsional untuk defisiensi vitamin B12.

Tujuan penelitian ini adalah untuk mengetahui pengaruh vitamin $\mathrm{B} 6$ dan $\mathrm{B} 12$ terhadap konsentrasi homosistein pada pasien LLA yang mendapat MTX intratekal (MTX IT) dan MTX intravena dosis tinggi (high dose/MTX HD).

\section{Metode}

Desain penelitian ini adalah case control study dengan pre dan post control group design. Penelitian dilakukan di Bangsal Anak RS Dr. M.Djamil Padang pada Januari 2017 sampai Juni 2017. Populasi penelitian adalah semua pasien LLA yang dirawat yang mendapat kemoterapi MTX IT dan MTX HD. Jumlah sampel minimal masing-masing kelompok yang dibutuhkan adalah 10 orang., Kriteria inklusi adalah pasien LLA yang mendapat kemoterapi MTX IT dan MTX HD fase konsolidasi standar risk (SR) dan high risk (HR). Kriteria eksklusi adalah pasien LLA fase induksi, intensifikasi dan fase maintenance, pasien LLA yang mengalami relaps, pasien LLA dengan demam neutropenia ataupun demam non neutropenia, pasien dengan kelainan kardiovaskular. Kelompok kontrol adalah pasien LLA yang mendapat MTX IT dan MTX HD. Kelompok perlakuan adalah pasien LLA yang mendapat MTX IT dan MTX HD dengan pemberian vitamin B6 dan B12 selama 6 minggu. Untuk menentukan sampel kelompok kontrol dan perlakuan dilakukan dengan teknik consecutive sampling.

Pemeriksaan konsentrasi homosistein serum dilakukan pada kedua kelompok dengan teknik ELISA pada Laboratorium Klinik Prodia Padang. Kelompok kontrol, pemeriksaan konsentrasi homosistein serum I (homosistein I kontrol) dilakukan setelah mendapat MTX IT dan MTX HD, dan pemeriksaan konsentrasi homosistein serum II (homosistein II kontrol) dilakukan setelah 6 minggu kemudian. Pada kelompok perlakuan, pemeriksaan konsentrasi homosistein serum I (homosistein I perlakuan) dilakukan setelah mendapatkan MTX IT dan MTX HD, kemudian pasien diberikan vitamin B6 $20 \mathrm{mg} /$ hari dan vitamin B12 $0,5 \mathrm{mg} /$ hari selama 6 minggu menggunakan vitamin $\mathrm{B} 6$ tablet $10 \mathrm{mg}$ (Pyridoxine $\mathrm{HCl} 10 \mathrm{mg}$ ) 
dan vitamin B12 $100 \mathrm{mcg}$ (Cyanocobalamin 100 $m c g$ ), produksi Kimia Farma, Bandung Indonesia, sesuai dengan formularium nasional. Setelah 6 minggu mendapatkan vitamin B6 dan B12 dilakukan pemeriksaan konsentrasi homosistein serum kedua (homosistein II perlakuan).

Data yang diperoleh dianalisis dengan sistem komputer SPSS. Dilakukan uji normalitas ShapiroWilk, untuk menghomogenkan subjek penelitian dan ditampilkan dalam bentuk deskriptif dan tabel serta dilakukan $u j i$ t-test dengan nilai p bermakna bila $\mathrm{p}<0,05$.

Penelitian telah dilakukan uji etik oleh Komite Etik Penelitian Fakultas Kedokteran Universitas Andalas Padang.

\section{Hasil}

Telah dilakukan penelitian pada pasien LLA yang mendapatkan kemoterapi MTX IT dan MTX HD dengan karakteristik subjek penelitian seperti tertera pada Tabel 1. Karakteristik subjek penelitian dibagi berdasarkan jenis kelamin, usia, tipe LLA, dan frekuensi mendapatkan MTX. Dilakukan uji normalitas ShapiroWilk, dengan hasil tidak ada perbedaan yang bermakna pada kedua kelompok ( $>>0,05)$, yang secara statistik karakteristik subjek penelitian pada kedua kelompok penelitian homogen dan dalam distribusi normal.

Penelitian ini mendapatkan konsentrasi rerata homosistein serum pada kedua kelompok setelah mendapatkan MTX IT dan MTX HD, yaitu homosistein I kontrol 11,72 $\pm 1,7067 \mu \mathrm{mol} / \mathrm{L}$ dan homosistein I perlakuan $12,05 \pm 2,0919 \mu \mathrm{mol} / \mathrm{L}$. Secara statistik tidak terdapat perbedaan yang bermakna ( $>0,05)$ tertera pada Tabel 2 .

Sementara konsentrasi rerata homosistein serum pada kelompok kontrol pada awal pemeriksaan (homosistein kontrol I) adalah 11,72 $\pm 1,7067 \mu \mathrm{mol} / \mathrm{L}$ dan setelah 6 minggu kemudian (homosistein kontrol II) adalah $11,630 \pm 1,4765 \mu \mathrm{mol} / \mathrm{L}$. Secara statistik juga tidak terdapat perbedaan yang bermakna $(p>0,05)$ seperti tertera pada Tabel 3.

Dengan pemberian vitamin B6 $20 \mathrm{mg} / \mathrm{hari}$ dan B12 0,5 mg/hari selama 6 minggu dapat menurunkan rerata konsentrasi homosistein serum $1,98 \pm 0,8108$

Tabel 1. Karakteristik sampel

\begin{tabular}{lcc}
\hline \multicolumn{1}{c}{ Karakteristik sampel } & Kelompok Kontrol & Kelompok Perlakuan \\
\hline Jenis kelamin: (n=\%) & & \\
Laki-laki & $6(30)$ & $7(35)$ \\
Perempuan & $4(20)$ & $3(15)$ \\
Usia (rerata \pm SD)(bulan) & $76,30 \pm 42,447$ & $70,60 \pm 7,494$ \\
Tipe ALL: (n=\%) & & \\
ALL tipe standar risk (SR) & $4(20)$ & $8(40)$ \\
ALL tipe high risk (HR) & $6(30)$ & $2(10)$ \\
Frekuensi sudah mendapat MTX (n=\%) & $0(0)$ & $1(5)$ \\
5 kali & $1(5)$ & $0(0)$ \\
6 kali & $4(20)$ & $3(15)$ \\
7 kali & $5(25)$ & $2(10)$ \\
8 kali & $0(0)$ & $4(20)$ \\
9 kali & & \\
\end{tabular}

Tabel 2. Konsentrasi homosistein serum kelompok kontrol dan perlakuan setelah mendapatkan MTX IT dan MTX HD

\begin{tabular}{lcc}
\hline Kelompok & Homosistein & $\mathrm{p}$ \\
\cline { 2 - 2 } $\begin{array}{l}\text { Kontrol } \\
\text { (homosistein I) }\end{array}$ & $\mathrm{X} \pm \mathrm{SD}(\mu \mathrm{mol} / \mathrm{L})$ & $0,704^{*}$ \\
\hline Perlakuan (homosistein I) & $11,72 \pm 1,7067$ & \\
\hline *uji t-test, nilai bermakna $\mathrm{p}<0,05$ & $12,05 \pm 2,0919$ & \\
\hline
\end{tabular}


Julispen S. Muhi dkk: Pengaruh pemberian vitamin B6 dan vitamin B12 terhadap konsentrasi homosistein serum pada LLA

Tabel 3. Konsentrasi homosistein serum kelompok kontrol setelah mendapatkan MTX IT dan MTX HD setelah 6 minggu kemudian

\begin{tabular}{lcc}
\hline Kelompok kontrol & Homosistein & $\mathrm{p}$ \\
\cline { 2 - 2 } & $\mathrm{X} \pm \mathrm{SD}(\mu \mathrm{mol} / \mathrm{L})$ & $0,562^{*}$ \\
\hline Kontrol (homosistein I) & $11,72 \pm 1,7067$ & \\
\hline Kontrol (homosistein II) & $11,630 \pm 1,4765$ & \\
\hline
\end{tabular}

*uji t-tes, nilai bermakna $\mathrm{p}<0,05$

Tabel 4. Konsentrasi homosistein serum kelompok perlakuan sesudah mendapatkan MTX IT,MTX HD dan setelah pemberian vitamin B6 dan B12

\begin{tabular}{lcc}
\hline Kelompok Perlakuan & Homosistein & $\mathrm{p}$ \\
\cline { 2 - 2 } & $\mathrm{X} \pm \mathrm{SD}(\mu \mathrm{mol} / \mathrm{L})$ & $0,001^{*}$ \\
\hline Perlakuan (homosistein I) & $12,05 \pm 2,019$ & \\
\hline Perlakuan (homosistein II) & $10,07 \pm 1,6526$ & \\
*Uji t-tes, nilai bermakna bila p $<0,05$ & & $\mathrm{p}$ \\
$\begin{array}{l}\text { Tabel 5. Perbedaan rerata konsentrasi } \\
\text { dan perlakuan setelah 6 minggu }\end{array}$ & $\mathrm{X}$ Kadar homosistein & $0,039^{*}$ \\
\hline Kelompok & $11,630 \pm 1,4765$ & \\
\hline $\begin{array}{l}\text { Kontrol } \\
\text { (homosistein II) }\end{array}$ & $10,07 \pm 1,6526$ & \\
\hline Perlakuan (homosistein II) & & \\
\hline
\end{tabular}

*uji t-tes nilai bermakna bila $\mathrm{p}<0,05$

$\mu \mathrm{mol} / \mathrm{L}$ atau menurunkan konsentrasi homosistein serum 16,43\%. Konsentrasi awal homosistein serum pada kelompok perlakuan (homosistein I perlakuan), yaitu $12,05 \pm 2,019 \mu \mathrm{mol} / \mathrm{L}$ dan setelah 6 minggu mendapatkan vitamin B6 dan B12 (homosistein II perlakuan) turun menjadi $10,07 \pm 1,6526 \mu \mathrm{mol} / \mathrm{L}$, berbeda bermakna secara statistik $(\mathrm{p}<0,05)$ seperti tertera pada Tabel 4.

Perbandingan antara konsentrasi homosistein serum setelah 6 minggu pada kelompok kontrol (homosistein II kontrol) 11,630 $1,4765 \mu \mathrm{mol} / \mathrm{L}$ dan kelompok perlakuan (homosistein II perlakuan) $10,07 \pm 1,6526 \mu \mathrm{mol} / \mathrm{L}$. Terdapat perbedaan rerata konsentrasi homosistein serum 1,56 $\pm 0,7008 \mu \mathrm{mol} / \mathrm{L}$. Perbedaan ini secara statistik bermakna $(\mathrm{p}<0,05)$, seperti tertera pada Tabel 5.

\section{Pembahasan}

Penelitian ini melibatkan 20 orang pasien ALL sebagai subjek penelitian dengan komposisi 65\% laki-laki dan $35 \%$ perempuan. Insiden rerata untuk seluruh jenis leukemia lebih tinggi pada laki-laki dibanding perempuan. Pada tahun 2009 diperkirakan lebih dari 57\% kasus baru leukemia pada laki-laki. ${ }^{6}$ Berdasarkan laporan dari Surveillance Epidemiology And End Result (SEER) di Amerika tahun 2009, perbandingan kejadian leukemia pada laki-laki dan perempuan adalah 57,22\%: 42,77\%. Menurut U.S. Cancer Statistics 2005, Amerika Serikat, didapatkan 18.059 kasus pada laki-laki $(55,37 \%)$ dan 14.557 kasus pada perempuan $(44,63 \%) .{ }^{2,3}$ Rerata usia $73,45 \pm 31,733$ bulan $(6,12 \pm 2,64$ tahun), Usia rerata kelompok kontrol 76,30 $\pm 42,447$ bulan $(6,35 \pm 3,53)$ tahun dan usia rerata kelompok perlakuan 70,60 $\pm 17,494$ bulan $(5,88 \pm 1,45)$ tahun. Penelitian Simamora ${ }^{12}$ di RSUP H. Adam Malik Medan tahun 2004-2007 melaporkan bahwa leukemia lebih banyak diderita oleh anak usia $<15$ tahun, khususnya LLA (87\%).

Kriteria berdasarkan tipe LLA saat diagnosis didapatkan 60\% tipe LLA SR (standar risk) dan 40\% tipe LLA HR (high risk), yang digunakan untuk menentukan prognosis pasien. Selain itu. banyaknya frekuensi mendapatkan MTX, baik IT maupun HD, sebelum pemeriksaan konsentrasi homosistein pada 
kelompok kontrol yang terkecil 6 kali dan terbanyak 8 kali, sedangkan pada kelompok perlakuan yang terkecil 5 kali dan terbanyak 9 kali. Hal tersebut akan berhubungan dengan akumulasi paparan MTX dan efek yang akan ditimbulkan. ${ }^{7-9}$

Neurotoksisitas yang terjadi setelah mendapat MTX disebabkan oleh jumlah paparan kumulatif MTX dan rute terapi MTX pada (insiden 5\%18\%). Efek MTX terhadap peningkatan konsentrasi homosistein dapat terjadi beberapa bulan sampai beberapa tahun setelah terapi MTX. ${ }^{5,6,9}$

Tidak didapatkan perbedaan rerata konsentrasi serum homosistein pada kedua kelompok pada awal pemeriksaan setelah mendapatkan MTX. Konsentrasi homosistein serum masih dalam batas normal. Sementara nilai normal konsentrasi homosistein adalah 5-15 $\mu \mathrm{mol} / \mathrm{L}$ berdasarkan nilai normal standar pemeriksaaan Laboratorium Klinik Prodia Padang. Hal tersebut serupa dengan penelitian Sadananda dkk $^{13}$ yang melaporkan nilai normal untuk homosistein 5-15 $\mu \mathrm{mol} / \mathrm{L}$. Penelitian lain melaporkan nilai normal homosistein kurang dari $13 \mu \mathrm{mol} / \mathrm{L}$. Rerata konsentrasi homosistein dalam darah saat puasa antara 6-12 $\mu \mathrm{mol} / \mathrm{L} .{ }^{14}$

Pada kelompok kontrol tidak terdapat perbedaan rerata konsentrasi homosistein serum. Selain itu juga didapatkan tidak terjadinya peningkatan homosistein setelah pemberian MTX IT dan MTX HD.

Wael $\mathrm{dkk}^{15}$ melaporkan hasil yang berbeda. Wael meyimpulkan bahwa konsentrasi homosistein terkait dengan neurotoksisitas dengan risiko yang lebih tinggi pada pemberian MTX HD $5 \mathrm{gr} / \mathrm{m}^{2}$. Dengan demikian terdapat hubungan antara konsentrasi homosistein awal dan akhir yang meningkatkan risiko terjadinya neurotoksisitas.

Peningkatan homosistein serum akan menimbulkan gejala kilinis dan risiko yang bervariasi. Konsentrasi homosistein 12-15 $\mu \mathrm{mol} / \mathrm{L}$ akan menyebabkan penurunan fungsi kognitif, $15-50 \mu \mathrm{mol} / \mathrm{L}$ faktor risiko untuk penyakit neurodegeneratif. Pasien homosisteinuria dengan konsentrasi homosistein serum yang tinggi mencapai 50-200 $\mu \mathrm{mol} / \mathrm{L}$, sekitar $20 \%$ akan memiliki risiko epilepsi. ${ }^{16}$ Kadar homosistein $13,4 \pm 14,6 \mu \mathrm{mol} / \mathrm{L}$ menimbulkan neuropati perifer, $8,1 \pm 2,5 \mu \mathrm{mol} / \mathrm{L}$ berakibat nyeri kepala. Konsentrasi homosistein $11,1 \mu \mathrm{mol} / \mathrm{L}$ memiliki lobus temporal medial $24,5 \%$ mengalami penipisan setelah 3 tahun bila dibandingkan dengan konsentrasi homositein $<11,1 \mu \mathrm{mol} / \mathrm{L}^{.}{ }^{17}$
Penelitian di Framingham, melaporkan konsentrasi plasma homosistein $14 \mu \mathrm{mol} / \mathrm{L}$ memiliki risiko 2 kali untuk terjadinya demensia. Risiko demensia meningkat $40 \%$ untuk setiap $5 \mathrm{mmol} / \mathrm{L}$ kenaikan homosistein plasma. Penelitian Optima menyebutkan perubahan materi substansia alba pada pasien dengan Alzheimers Desease $(A D)$ adalah 1,4 kali pada konsentrasi homosistein $15 \mu \mathrm{mol} / \mathrm{L}$. Penelitian di Rotterdam melaporkan setiap peningkatan $1 \mu \mathrm{mol} / \mathrm{L}$ konsentrasi plasma homosistein berhubungan dengan peningkatan 6\%-7\% pada risiko iskemik dan peningkatan 1,4 kali lipat risiko stroke iskemik dengan konsentrasi plasma homosistein $12,7 \mu \mathrm{mol} / \mathrm{L}^{18}$

Pada penelitian ini tidak dilakukan penilaian gejala dan tanda klinis neurotoksisitas akibat peningkatan homosistein pada subjek penelitian.

Setelah 6 minggu pemberian vitamin B6 dan B12 pada kelompok perlakuan terdapat perbedaan rerata konsentrasi homosistein serum yang bermakna, rerata pada kelompok kontrol 11,630 $\pm 1,4765 \mu \mathrm{mol} / \mathrm{L}$ dan kelompok perlakuan $10,07 \pm 1,6526 \mu \mathrm{mol} / \mathrm{L}$, sehingga terdapat perbedaan rerata sebesar $1,56 \pm 0,7008 \mu \mathrm{mol} / \mathrm{L}$.

Saat awal pemeriksaan dan setelah 6 minggu mendapatkan vitamin B6 dan B12 pada kelompok perlakuan terjadi kecenderungan penurunan rerata konsentrasi homosistein serum sebesar $1,98 \pm 0,8108$ $\mu \mathrm{mol} / \mathrm{L}$ atau menurun $16,43 \%$.

Efek pemberian vitamin B6 dan B12 terhadap penurunan konsentrasi homosistein telah dilaporkan oleh Johan $\mathrm{dkk}^{19}$ dengan pemberian vitamin B6 selama 6 minggu dengan dosis $20 \mathrm{mg} /$ hari dapat menurunkan beban post methionine sehingga dapat menurunkan konsentrasi serum homosistein total. Meta-analisis yang diterbitkan oleh Homocysteine Lowering Trialists Colloboration 1998, pemberian vitamin B6 16,5 mg sehari selama 6 minggu bersamaan dengan asam folat dan vitamin B12 memiliki efek menurunkan homosistein walaupun secara statistik tidak bermakna. ${ }^{11}$

Penelitian lain melaporkan bahwa pemberian tambahan vitamin $\mathrm{B} 12$ rerata $0,5 \mathrm{mg} /$ hari dan vitamin B6 rerata 16,5 mg/hari akan menurunkan 7\% konsentrasi homosistein dan bila ditambah dengan pemberian asam folat menurunkan sebesar 25\%. ${ }^{11}$ Sneha $\mathrm{dkk}^{20}$ melakukan penelitian estimasi konsentrasi folat dan vitamin B12 pada 102 pasien keganasan pada anak, 36,3\% mengalami gangguan deffisiensi vitamin B12 dan 62,7\% mengalami deffisiensi folat. Konsentrasi rerata vitamin B12 serum pasien keganasan 


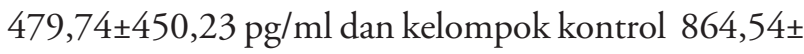
$733,49 \mathrm{pg} / \mathrm{ml}$. Sementara rerata konsentrasi folat pasien keganasan 8,91 $\pm 8,31 \mathrm{ng} / \mathrm{ml}$ dan kontrol 12,73 $\pm 15,96$ ng/mL. Penelitian mendapatkan bahwa pada pasien LLA rerata konsentrasi vitamin B12 482,06 480,29 $\mathrm{pg} / \mathrm{mL}$, sedangkan konsentrasi asam folat serum yaitu $9,23 \pm 8,53 \mathrm{ng} / \mathrm{mL}$. Dengan demikian, disimpulkan bahwa konsentrasi serum vitamin B12 paling rendah pada pasien LLA.

Sadananda $\mathrm{dkk}^{10}$ melakukan penelitian case control study pada 86 pasien LLA, melaporkan bahwa konsentrasi homosistein plasma meningkat pada pasien LLA yang disertai dengan status deffisiensi riboflavin. Sedananda ${ }^{13}$ juga melakukan penelitian pada pasien LLA L1, LLA L2, dan LLA L3, melaporkan bahwa asam folat dan vitamin B12 berkorelasi secara statistik menurunkan konsentrasi serum homosistein dengan nilai normal vitamin B12 180-900 pg/ml dan asam folat 3-17 $\mathrm{ng} / \mathrm{ml}$.

Keterbatasan penelitian ini adalah pemeriksaan konsentrasi homosistein serum dimulai pada fase konsolidasi, tidak diperiksa mulai dari awal sebelum pemberian MTX. Dengan demikian tidak didapatkan nilai pembanding konsenstrasi homosistein serum normal pada masing-masing sampel sebagai patokan dasar sebelum dan sesudah mendapatkan MTX. Penelitian ini hanya menghitung frekuensi pemberian MTX yang telah diberikan pada pasien saat pemeriksaan awal homosistein (homosistein I) dan pada pemeriksaan homosistein setelah 6 minggu (homosistein II). Penelitian ini mengabaikan banyaknya MTX yang telah didapat pasien saat pemeriksaan homosistein II dan juga tidak dilakukan penilaian klinis, baik tanda dan gejala neurotoksisitas akibat peningkatan konsetrasi homosistein.

\section{Kesimpulan}

Pemberian vitamin B6 dan B12 pada pasien LLA yang mendapat kemoterapi MTX IT dan MTX HD dapat menurunkan konsentrasi homosistein serum. Disarankan, sebaiknya dilakukan pemeriksaan konsentrasi homosistein serum secara berkala pada pasien LLA yang mendapatkan kemoterapi MTX IT dan MTX HD. Hal tersebut untuk mencegah peningkatan konsentrasi homosistein serum yang dapat menimbulkan neurotoksisitas, terutama pasien yang telah mendapatkan MTX yang berulang dalam jangka waktu yang lama. Sebaiknya, perlu juga diberikan vitamin B6 dan vitamin B12 sehingga dapat menurunkan konsentrasi homosistein serum dan diperlukannya penelitian lanjutan untuk menilai gejala dan tanda neurotoksisitas.

\section{Daftar pustaka}

1. David G, Archie B, AK Ritchey. The leukemia. Dalam: Kliegman, Stanton, ST Geme, Schor and Behrman, penyunting. Nelson text book of pediatrics. Edisi ke-19. Philadelphia: Elsevier Saunders; 2011.h.1732-9.

2. Ching-H P, Leslie L R, A Thomas. Seminar. Acute lymphoblastic leukemia. The Lancet 2008;37:1030-43.

3. Malcolm AS, Lynn AG, James GG, Julie AR. Leukemia. National Cancer Institute SEER Pediatric Monogr 2007:1735.

4. Unit Koordinasi Kerja Hematologi-Onkologi IDAI. Protokol pengobatan leukemia limpoblastik akut anak tahun 2013 (Indonesian Childhood ALL-2013 Protocol). Jakarta: UKK Hematologi-Onkologi IDAI 2013.h.1-29.

5. April FE, Tracy TB, John WH. Diffusion and perfusion imaging in subacute neurotoxicity following high-doseintravenous methotrexate. Neuro-Oncology 2007;9:373-7.

6. Laura I, Paolo M, Cesare C, Francesco G, Antonio R, Riccardo R. Long-term cognitive outcome, brain computed tomography scan, and magnetic resonance imaging in children cured for acute lymphoblastic. Leukemia Cancer 2002;95:2562-70.

7. Fulvia B, E Brannon M, Fred HL,dkk. Recurrent intrathecal methotrexate induced neurotoxicity in an adolescent with acute lymphoblastic leukemia: serial clinical and radiologic findings. Pediatr Blood Cancer 2009;52:293-5.

8. Daniela AB, Rima MD. Acute methotrexate neurotoxicity with choreiform movements and focal neurological deficits: a case report. Southern Med J 2009;102:1071-3.

9. Inaba H, RB Khan, FH Laningham, KR Crews, C-H Pui, NC Daw. Original article: clinical and radiological characteristics of methotrexate-induced acute encephalopathyin pediatric patients with cancer. Annals Oncol 2008;19:178-84.

10. Sadananda AM, Sunil C, Girija R, Appaji L, Aruna K and Lakshmi K. Association between plasma homocysteine and riboflavin status in acute lymphoblastic leukemia in children. Ind J Clin Biochemist 2009;24:257-61.

11. JJ Strain, L Dowey, M Ward, K Pentieva, H McNulty. B-vitamins, homocysteine metabolism and CVD proceeding. Nutr Soc 2004;63:597-603.

12. Simamora I. Karakteristik penderita leukemia rawat inap di 
Julispen S. Muhi dkk: Pengaruh pemberian vitamin B6 dan vitamin B12 terhadap konsentrasi homosistein serum pada LLA

RSUP H. Adam Malik Medan Tahun 2004-2007, skripsi. Medan: FKM Universitas Sumatera Utara; 2009.

13. Sadananda A, Sunil C, Girija R, Appaji L, Laksmi. Homosistein, vitamin B12 and folate status in pediatric acute lympoblastic leukemia. India J Pediatric 2008;75:235-8.

14. Hauke R, Achim B, Anne D, dkk. Population PK/PD model of homocysteine concentrations after high-dose methotrexate treatment in patients with acute lymphoblastic leukemia. Plos One 2012;7:e46015.

15. Wael Z, Mohamed S, Mona K, Sanaa K. The impact of homocysteine level on methotrexate induced neurotoxicity in children treated with St Jude total XV acute lymphoblastic leukemia protocol. Intern J Can Ther and Onc 2016;4:1-7

16. Rima O, Wolfgang $\mathrm{H}$. Mechanisms of homocysteine neurotoxicity in neurodegenerative diseases with special reference to dementia. FEBS 2006;580:2994-3005.

17. Miese FR, Schuster K Pierstorff M, Karenfort HJ, Laws AB, A Saleh. Case report: magnetization transfer imaging provides no evidence of demyelination in methotrexate-induced encephalopathy. Am J Neuroradiol 2011;32:E110-2.

18. Kartik S, Amer N, Nae JD, Jin JL. Elevated plasma level of homocysteine is an independent risk factor for peripheral neuropathy. Brit J Med Res 2014;4:161-9.

19. Johan BU, Annatije VD Merwe, Rhena D, Robert HA, Sally PS, Reiner R. The effect of a subnormal vitamin B6 status on homosistein metabolisme. J Clin Invest 1996;98:177-84.

20. Sneha T, Kalpana S, Anand R, Bhawna S, Abbas Ali M, Archana K. Estimation of serum folate and vitamin B12 Levels in children with hematologic malignancies. Gomal J Med Sci 2014;12:89-92. 